ことはできなかった。

（4）第 12 図中，曲線 oe $A$ に相当する分枝上の 点は測定が困難てあった.これは加振力が構造および 空気の隇衰力に比へてて小さすぎたことと, 振動検出用 ピックアップとして拘束を避けるため加速度計を用い たためと考えられる. また，漱近線の opに沿った分 枝上において振動加速度と加振力との位相差は他の漱

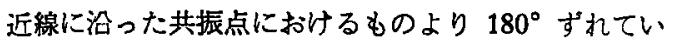
ることが钼察された。

（5）ダンパーなしの実験において，空気および棈 造上の減衰力が存在するにもかかわらず，実験結果の 不安定振野域が淢衰がないとした計算結果よりも広い 傾向にあったことは， $K_{y}$ が有限の值であったためと 考えられる. 第 11 図に $s=1$ と仮定した計算結果を あわせてプロットした.

（6）第 13 図に示すように 3 枚翼機，4枚翼機の 地上共振特性の間には本的な差は認められない，し かし, 4 枚翼機は翼数が增加したため $\Lambda_{3 . x}$ が大きく なり僅かに不安定振動域が広くなった。

（7）ドラッグ・ヒンジのオフセットによってある 程度連成固有掁動数をコントロールすることができ る.すなわち,オフセットを大きくすれば不安定振動 域は主翼回転数の高い方へ移り，その範囲が幾分狭く なる.

（8）ダンパー付の回転翼機模型は線型振野を行な わなかったが不安定振動域はほほ理論計算と一致し た.非線型振動になった理由は，ダンパー自身に存在 していた僅かな非楾型特性とダンパー連結部における 拘束の二つが考えられる.

\section{5. あとがき}

以上述へててきように，CoLEMAN の理論は線型振 動域において良く実験と一致した。

いうまでもなく，理想化した本実験模型といえども 機体の上下動, 数個のばねの組み合わせ, 重力等の影 㸷は避けることができず，それらがすへて実験的に決 定した有效量，有効ばね定数に含まれて，しかもな お理論と実験が一致したことは，一応この理論が工学 上満足すべきものであると結論することができる.し かし, CoLEMAN の理論は機体の運動，特に脚のオレ オの影響等に関して爰密性を久く. 本実験結果がさら に高度な地上共振に関する理論的発展の一助となれば 筆者等の望外の幸いとするところである。

この実験は昭和 33 年度運輸省試験研究補助金をう けて行なったものて，本実験について，種々御指皆， 御協力下さった運輸省航空局，運輸技術研究所の方々 および大阪府立大学工学部航空工学科の方々に厚く感 謝する.

\section{节文献}

1) Coleman, R.P. \& Feingol.d, A.M. : Theory of belfexcited mechanical oscillations of belicopter rotors with hinged blades. NACA. T. N. 3844, (1957).

2) DeUtsh, M.L. : Ground vibrations of helicopter. J. Aero. Sci.. Vol. 13, No. 5 (1946/5), D. 223.

8) WAGNER. R.A.: Vibration hand book for helicopters, P.B. 111299, (1954).

4) Silvetra. M.A., Maglierr, D.J. \& BrooKs, G.W.: Results of an experimental investigation of emall viscous dampers, NACA. T.N. 4257. (1958).

\title{
主要構造部の検查間隔の設定に関する試考*
}

\section{A Trial of the Determination of Major Structure Inspection Period}

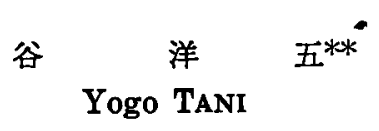

\begin{abstract}
The determination of inspection period of main structure has been accomplished based upon the operator's experience about their operating fleets.

But the modern air transport is designed aiming at the increasing of fatigue resistance and the lower crack propagation rate, and they adopt completly
\end{abstract}

*昭和 84 年 11 月 17 日原梳受理

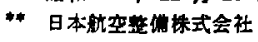

the fail safe principle.

To conform with above situation, the inspection period should be determined as theoretically as possible.

The following analysis is a trial for this way and stands on the basis of the fail-safe test results, the load spectrum, the components fatigue tests, the critical incident rate and the statistical method. 


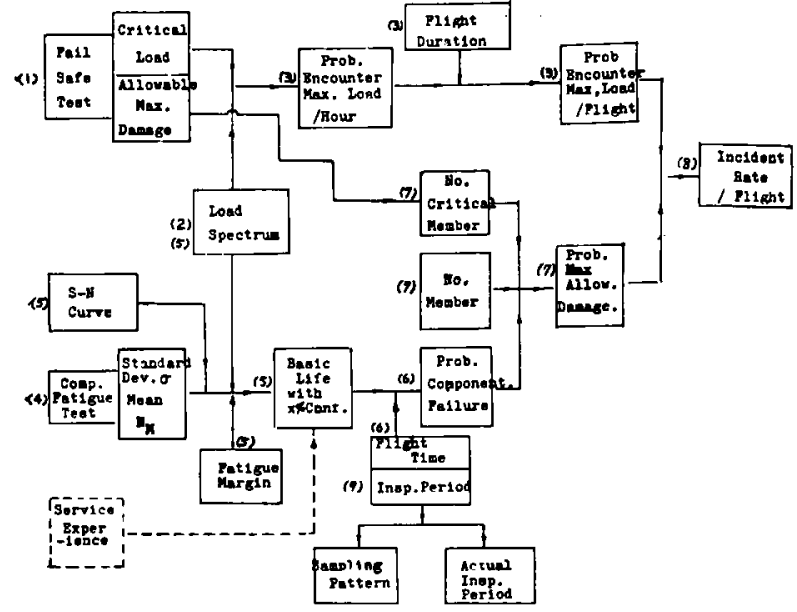

第 1 図 The Related Ideas about Inspection Period Analysis

\section{1. 赫言}

民間輸送機の構造部の検査間隔は運航業者および篮 督官庁により主として使用程験により決定されてきた が，近代的な高速機では製造時において

各部分の耐疲労性の向上

渑裂の進行度の低下

フェイル・セイフ構造の徹底的採用

等により，安全性は著しく向上している.そこでこの ような機体に対する検查間隔は従来に較べてかなり理 論的に決定できると考えられるので，その方法に関す る一試案を示す.

\section{2. 設定方法}

検查間亚をできるだけ理論的に設定するために必要 な概念とそれらの相互の関連性について，第 1 図に示 す. 図中のブロックに付した数字は以下の説明の各項 の番号に相応する.

なお計算例として日本航空が使用する予定の大型シ エット旅客機の場合について示す.

1. フェイル・セーフ試験の結果 例えば CAR 46.270 等により指定されるが如き静的試験さ，こ れに合格することにより，機体のある部分についての 許容損傷度とこれに対応する許容荷重が得られる.

計算例：主翼の場合で，縦通材 2 本を切断し， $V_{c}{ }^{+}$ の際の制限荷重（曲げモーメント，莮断荷重および 㨭りモーメント)の $80 \%$ をかけて試験を行なって いる.

2. 荷亚の頻度分布の想定 将来その機体が運航さ れる際に，蒙るであろう荷重の頻度分布は，種々のデ 一タより予測しうる.

計算例: Bo Lundberg の標準突風頻度 ${ }^{12}$ 使用し た。なお最大許容荷重に遭遇する確率の計算にはこ れで充分てあるが，疲労寿命の計算には他の原因に
よる荷重をも考虑しなけれはなななが，現 在データが不十分であ.るのでこれに対す る修正として損偒に対する各種の荷重の貢 献の割合を仮定した.（7. 参照）

3. 樶大許容荷而に遇する確率 最大許 容荷重に相当する突風の值と荷重の頻度よ り， 1 運航時間中に最大許容荷重に遭遇する 確率 $P_{L}$ を計算することができる.

計算例：制限荷重の $80 \%$ に相当する突風 は $34.2 \mathrm{ft} / \mathrm{s}$,これに遭遇する確率は $10^{6}$ 哩の飛行中 2.22 回, すなわち 982 飛行時 間に 1 回となる.

なおブロック・タイムの平均 $h$ は 6.48 時 間である.

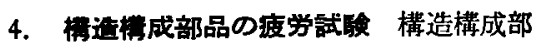
品の疲学試験としては現状ではプログラム荷 重をかけることはあまりなく一定の応力振幅て行なわ れることが多い。この場合について述べと標本に対 して疲労による琶裂の発生まての繰返し回数の平均お よび標準偏差を得ることがで，その結果より因集団 の平均をある信頼度をむって定めることか゚できる。こ の値は $S-N-P$ 曲線上の一点を与えることとになる。

計算例: 標本の数は 4 個で第 1 表の如くである.

第 1 表では最高および最低の值のみが与えられてい て，標準偏差が末知であるので最低値をもって好集団 の平均としてこの際の信頼度は $80 \%$ ゙ であるした。

第 1 表 構成部分の疲労試験結果

\begin{tabular}{|c|c|c|c|c|}
\hline \multirow{2}{*}{ 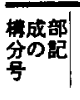 } & \multirow{2}{*}{ 棈 成 部 分 } & \multicolumn{2}{|c|}{ 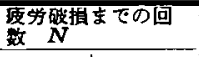 } & \multirow{2}{*}{$\begin{array}{l}\text { 部材数 } \\
\mathbf{a} / \mathbf{m}\end{array}$} \\
\hline & & 最 大 & 最 小 & \\
\hline $\mathbf{A}$ & $\begin{array}{l}\text { wing. basic gtructure } \\
\text { skin \& gtringer comb. }\end{array}$ & $\mathbf{8 7 8}, 000$ & 872,000 & $14 / 3$ \\
\hline $\mathbf{B}$ & $\begin{array}{l}\text { A と同椂 } \\
\text { 但し gtringer に fuel } \\
\text { trang- hole } あ り\end{array}$ & $\begin{array}{l}\text { 上記 } \\
\text { の } 8\end{array}$ & & $20 / 3$ \\
\hline C & 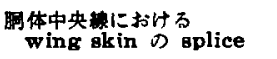 & 240.000 & 220,000 & $20 / 3$ \\
\hline $\mathbf{D}$ & $\begin{array}{l}\text { wing. etringer integral } \\
\text { end fitting }\end{array}$ & $\begin{array}{l}\text { 上邹 } \\
\text { と同 }\end{array}$ & & $20 / 1$ \\
\hline $\mathbf{E}$ & $\begin{array}{l}\text { wing, etringer } \\
\text { shear splice }\end{array}$ & 255,000 & 220,000 & $8 / 1$ \\
\hline
\end{tabular}

5. 楼成部品の平均毒命およびそのちらばリ $S-N$ 曲線，荷重の頻度および $1 G$ に対する応力と終極応力 との比とを勘案することにより，ある信頼度 $(S-N$ 曲 楾の 信頼度と 合致する) をもって，その構成部分の $50 \%$ 寿命を得ることができる.この唛命に対してち らはりり Log-Normal 分布を成すと考える.

計算例: $S-N$ 曲楾の仮定および荷重の頻度の仮定 はすべて Bo Lundberg") のやり方にしたがって次 式を用いる. 


$$
\begin{aligned}
& L_{b}=\frac{2400}{\Gamma(\overline{\beta+1)}}\left(\frac{51.8 k_{A f}}{b_{0}}\right)^{\beta} \\
& \beta=-\frac{\log N_{1}-3.88}{\log S_{a N}-\log b_{0}}
\end{aligned}
$$

ただし

$L_{b}$ : 構成部分の $50 \%$ が疲労破損を扎こすをでの飛 行哩数

$k_{\Delta f}:$ 疲労を考虑した安全率で（3）式で定義される $(=1.180)$

$$
S_{u l t}=1.5 n_{A} k_{A f} S_{1}
$$

$S_{u l t}$ : 終極荷重に相当する gross stress $(=53,100$ psi)

$n_{\boldsymbol{A}}:$ 制限荷重係数 $(=2.5)$

$S_{1}: 1 G$ 荷重に相当する gross stress $(=12,000 \mathrm{psi})$

$N_{1}$ : 荷重 $S_{a N}$ により㙇裂の発生するまでの繰返し 数

$S_{a N}$ : 荷重比で, 試験応力/終極応力 である.

$b_{0}: S-N$ 曲線の形状をきめる定数で統計的にきまる $(=2.904)$

6. 永行時間亡搆成部分の破損の確率 $\boldsymbol{P}_{0(T)}$ 各(累 阵) 飛行時間におけるその構成部分の破損の確率を前 記 5. の分布より得ることができる.

7. 機体構造として最大許容破損限度に達する確率 $\boldsymbol{P}_{\boldsymbol{F}(T)}$ 実際には機体の一部分（例之ば主翼とか尾部） では critical さの程度の 異なる多種の部材よりなる が，破損の確率は最も critical なものに比して他のも のは無視できるほど小さいと仮定する．また機体の一 部分が同一寸法の critical な部材よりなり立ち, かつ 各部材には相等しい荷重がかかっている，すなわち各 部材は相等しい破損の確率をもっていると仮定する と，上記の確率は（4）式で与えられる

$$
P_{F(T)}=\left(\begin{array}{c}
q \\
q_{c}
\end{array}\right)\left(m P_{0(T)}\right) q_{c}
$$

ただし

$q$ ：荷重の伝達に对して並列になっている部材の数

$m$ : 各部材が直列の構成部分よりなる際におけるそ の数

$q_{c}$ : 許容しうる最大破損部材の 数. これはフェイ ル・セーフ試験より求めることができる.

計算例:

$$
\begin{aligned}
& q: \text { 第 } 1 \text { 表に示す } \\
& q_{c}=2 \text { (第 } 1 \text { 章) }
\end{aligned}
$$

なお荷重頻度として突風以外のものは採用しなかっ たのて，これに対する補正として REF.(2)によれば ジェット輸送機の各種荷重源による疲労破損の貢献度 は主翼の付根に対して突風が約 $50 \%$ ，その他のもの が約 44\% となっているので安全側として（4）式で 与えられる值の 2 倍の確率をとった。
8. Incident Rate/Flight Incident はある時間 飛行したときそれまての検査で発見されない龟裂（破 損) が生していて，たまたまその飛行中に最大許容荷 重以上のものをうけることにより起ると仮定しよう. 1 飛行あたりに Incident をうける確率 $\left(I_{(T)}\right)$ は（5） 式で表わされる.

製造後第 1 回の検査までは

$$
I_{(T)}=2 P_{L} \int_{T}^{T+h} P_{F(T)} d T
$$

となるが, hか～$T$ に比して充分小さくて, $P_{F(T)}$ は 飛行時間中一定と仮定すると近似的に

$$
I_{(T)}=2 h P_{L} P_{F(T)}
$$

第 $n-1$ 回の検查と第 $n$ 回の検查の間では

$$
I_{(T)}=2 h P_{L} \frac{\int_{T n-1}^{T} \frac{\frac{d P_{F}}{d T} d T}{1-\int_{0}^{T} \frac{d P_{F}}{d T} d T}}{1 T}
$$

たたしし

$T_{n-1}: n-1$ 回目の検査の実施されたときの総飛行 時間

なお係数 2 は本計算例のため 7.により定まったも ので，一般化された式では他の值となる.

計算結果: 第 2 図に示す.

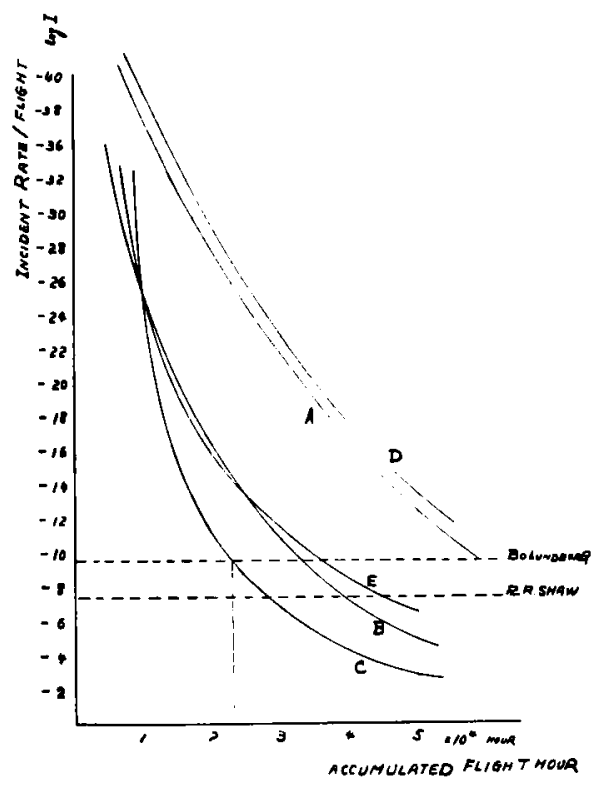

第 2 図 Flight Hour と Incident Rate の関係

9. 検㚗間隔 Incident Rate/Flight がある critical な值を超えないように決定する．ただしここで与えら れる検查間隔は equivalent なもので実際のものとは 異なる。

計算例 : critical incident rate は Bo Lundberg ${ }^{5)}$ および R.R. Shaw ${ }^{6)} に よ り$ 示されているが(次表の 
中の*のついた值)これより critical section に対す る incident rate を次の表により得る.

\begin{tabular}{|c|c|c|c|}
\hline 提弿者 & 第体全体 & 機体全体 & Critical Section \\
\hline Bo Lundberg & $\left|0.4 \times 10^{-9 *} / \mathrm{Hr}\right|$ & $2.6 \times 10^{-9} / \mathrm{Flt}$ & $2.6 \times 10^{-10} /$ Flt \\
\hline R.R. Shaw & & $4 \times 10^{-7 *} / \mathrm{Flt}$ & $4 \times 10^{-8} /$ Fit \\
\hline
\end{tabular}

たたし: 1 我行時間は 6.48 時间

機体は5 佃（対称性により10 個）の同程度に最も critical な部分を含むことを仮定し，critical な部分の eritical incident rate/flight としては㮝体全体の $1 / 10$ をとっ t.

よって第 1 回目の㭘查は第 2 図の各曲線が 上記の critical incident rate と交わる点で表わされる飛行時 間で行なわなければならぬ.（第 2 回以後は省略）

\section{3. 結 锉}

本方法により近代高速輸送機の主要構造部分に関す る検查間隔の設定ができる.計算例により得た結果は 大体従来の経験より推定される検查間隔より約 2 倍程 度大きく出ているがこれは，従来の検查間隔が単に耐 空性を保つ目的のみならず，効率のよい整備という点 を含んでいるため当然のことと考えられる.しかし本 方法には以下の如き不供をも含んているのでなお将来 開発の余地がある。

A. 許容される Incident Rate の磼立 これにつ いては種々の案が発表されているが，未だ決定的なむ のがないので，明確な規定が欲しい，

B. 荷重頻度 突風以外の荷重の頻度に関するデー タが不足のため計算例では，各荷重の破損に対して果 す割合を仮定したがこれはやはり，全荷重に対して正 攻法て計算すべきである。

C. 疲労寿命のちらばリこれは Log-Normal 分 布を仮定したが，多くの機体の場合逐次改修を行なっ て行くのでむしろ normal 分布の方が近似しているか も知れないので分布の形についてはもっと検討を要す る.

D. 疲労寿命 (50\%) の決定 $S-N$ 曲線の想定は - _...—抄 録 (統き)

(87 面より敬く)

ども，人工衛星からは入手できる.雲形は地上の钼測 者からは下から見たものであるが，衛星は上から見た 情報をあたえる．また渦とか，雲の列とか，前線性の 雲の配置とかいう cloud patterns の大観は, 従来の 気象䚁測では到底得られないで，人工衛星のみが与え

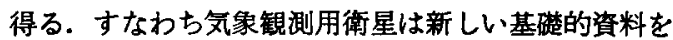
提供する.

衛星による雲の観測ブログラムの現状をのべると， (1) 1959 年 2 月 17 日発射したバンガート第 2 号は二
（1）式に含めて総合的に行なったが過去の試験結果か ら得た各種のノッチ係数に相㡱する $S-N$ 曲線群より equivalent なむのを見つけてこの曲線を用いる方が良 いと考えられる.

E. サンブリングと実際の検古間隔 本方法で与え られる検查間隔は仮想的なもので適宜にサンブリング 方式を用いることにより実際の検查間隔を延長するこ とができる。これに関しては Hayden" の論文があ る.

F. 裂の進行に関して 構成部材に対しては象裂 の発生とともにその部材は破損すると仮定し，逆に一 つの構成部材の破損ののち，裂の進行によりその降 の構成部材が破損するようなことは検查間ではあり得 ないすなわち龟裂の隣の部分への進行の割合は非常に おそいか，阻止されるかまたは外部より発見できるこ とを仮定したが，この点も再考を要する.

G. その他 本方法は第 1 図に示す如くに，疲労試 験結果を用いないで同種類の機体におおる使用経験を 勘案して検查間隔を決めうることを示している.

なお本文作製にあたり，航空技術研究所の上山忠夫 氏より，御親切な注意を頂いたことを感謝する。

\section{荟考献}

1) Bo Lundberg : Fatigue Life of Airplane Structure J.A.S Vol. 22, No. 6. p. 968 .

2) P. Donely : The Measurement And Asgessment of Repeated Loads on Airplane Components 3rd Meeting of Structure and Materials, Panel of AGARD. Fig 29.

8) F.A. MeClintock: The Statiotical Planning and Interpretation of Fatigue Tests. Metal Fatigue, Mc Graw-Hill. 1959, p. 113.

4) 上蚁 1) と同滕 p. 389.

5) Bo Lundberg: Notes on The Level of Safety and the Repair Rate with Regard to Fatigue in Civil Aircraft Structures 11 th Tech. Conf. IATA Aug. 1958.

6) R.R. Shaw: Level of Safety Achieved by Periodic Inspection for Fatigue Crack J.R.A.S. Vol. 58, No. 10. p. 721.

7) H.J. Hayden :- Contribution of Fatigue Testing to Fatigue Resistant Design 11 th Tech. Conf. IATA. Aug. 1958.

つの光電池をつみこんで, 衛星から見た雲のたたずま いを磁気テープに記憶させる. 監視局 (readout stations）の上に来たとき，そこからの指令で記憶させ られた情報を地上へつたえられるようになっていた。 しかしこの実験では思わしい結果か得られなかっ た. (2) 現在試作中の Project TIROS によると, $50^{\circ} \mathrm{N}$ と $50^{\circ} \mathrm{S}$ の間を高度数百マイルで回る衛星が発 射され，テレビジョン・カメラがのせられることにな っている.それてととられたスナップショットは磁気テ (80 頁へ兟く) 